\title{
Metal alloys for the new generation of compressors at hydrogen stations: Parametric study of corrosion behavior
}

\author{
Arjomand Kermani, Nasrin; Petrushina, Irina; Nikiforov, Aleksey Valerievich; Rokni, Masoud
}

Published in:

Renewable Energy

Link to article, DOI:

10.1016/j.renene.2017.08.066

Publication date:

2018

Document Version

Peer reviewed version

Link back to DTU Orbit

Citation (APA):

Arjomand Kermani, N., Petrushina, I., Nikiforov, A. V., \& Rokni, M. (2018). Metal alloys for the new generation of compressors at hydrogen stations: Parametric study of corrosion behavior. Renewable Energy, 116(Part A), 805-814. https://doi.org/10.1016/j.renene.2017.08.066

\section{General rights}

Copyright and moral rights for the publications made accessible in the public portal are retained by the authors and/or other copyright owners and it is a condition of accessing publications that users recognise and abide by the legal requirements associated with these rights.

- Users may download and print one copy of any publication from the public portal for the purpose of private study or research.

- You may not further distribute the material or use it for any profit-making activity or commercial gain

- You may freely distribute the URL identifying the publication in the public portal 


\section{Accepted Manuscript}

Metal Alloys for The New Generation of Compressors at Hydrogen Stations:

Parametric study of Corrosion Behavior

Nasrin Arjomand Kermani, Irina Petrushina, Aleksey Nikiforov, Masoud Rokni

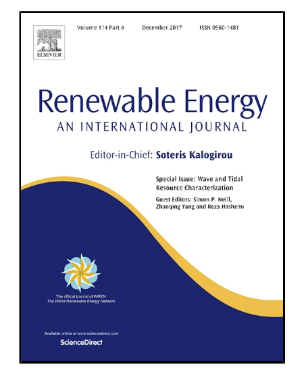

PII:

S0960-1481(17)30824-8

DOI:

10.1016/j.renene.2017.08.066

Reference:

RENE 9164

To appear in:

Renewable Energy

Received Date:

01 March 2017

Revised Date:

18 August 2017

Accepted Date:

23 August 2017

Please cite this article as: Nasrin Arjomand Kermani, Irina Petrushina, Aleksey Nikiforov, Masoud Rokni, Metal Alloys for The New Generation of Compressors at Hydrogen Stations: Parametric study of Corrosion Behavior, Renewable Energy (2017), doi: 10.1016/j.renene.2017.08.066

This is a PDF file of an unedited manuscript that has been accepted for publication. As a service to our customers we are providing this early version of the manuscript. The manuscript will undergo copyediting, typesetting, and review of the resulting proof before it is published in its final form. Please note that during the production process errors may be discovered which could affect the content, and all legal disclaimers that apply to the journal pertain. 


\title{
Metal Alloys for The New Generation of Compressors at Hydrogen Stations: Parametric study of Corrosion Behavior
}

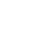

4

5

6

7

*Correspondence should be addressed to: Irina Petrushina

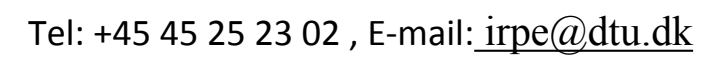

\begin{abstract}
Compressors are one of the most costly components at hydrogen stations, which leads to the high price of hydrogen production. The substitution of a solid piston with ionic liquid is a promising option that may solve some of the challenges related to conventional reciprocating compressors and, consequently, significantly reduce the final cost of hydrogen production. The correct choice of ionic liquid and construction materials is critical for avoiding significant corrosion problems. Hence, the objective of this study is to evaluate the compatibility of various austenitic stainless steels and nickel-based alloys as construction materials in contact with $80^{\circ} \mathrm{C}$ ionic liquids in an ionic liquid hydrogen compressor, considering the role of parameters such as the temperature, viscosity, ionic liquid cation and anion, and water absorption.
\end{abstract}

The results show that temperature contributes to increasing the corrosion rate. However, even at $80{ }^{\circ} \mathrm{C}$, the very low corrosion current densities proved that all of the tested alloys are safe to use as construction materials. AISI 347 showed very high corrosion resistance in all of the ionic liquids. The highest corrosion resistance among all of the tested alloys was observed in trihexyltetradecylphosphonium bis (trifluoromethylsulfonyl) imide, which had a relatively high viscosity and the lowest water content.

Keywords: Ionic liquids, Hydrogen, Hydraulic and pneumatic industry, Gravimetric method, Tafel plots, Corrosion resistance

\section{Introduction}

Many environmental analyses show a strong connection between $\mathrm{CO}_{2}$ emissions, due to fossil fuel consumption, and global warming [1]. Therefore, over the last several decades, attention has been 
given worldwide towards sustainable solutions that can reduce $\mathrm{CO}_{2}$ emissions. Currently, more than $95 \%$ of all global energy in the transport sector is supplied by fossil fuels. This sector is responsible for over $23 \%$ of all energy-related $\mathrm{CO}_{2}$ emissions [2,3]. In this context, fuel cell vehicles have gained attention as a long-term solution that would enable the use of renewable energy for transportation with zero carbon and particle emission [4]. It is expected that with a $25 \%$ share of fuel cell electric vehicles on the roads by 2050 , the cumulative transport-related carbon emissions will be reduced by up to $10 \%$ $[5]$.

To establish a solid ground for the significant market penetration of fuel cell vehicles, challenges such as fast refueling, long driving range and high energy efficiency must be overcome. To produce fuel cell vehicles with a driving range that is comparable with the current technologies based on fossil fuels, onboard high-pressure hydrogen storage seems to be a promising option. The high-pressure storage of hydrogen in tanks requires the compression of hydrogen to more than 700 bar at refueling stations and the cooling of hydrogen to approximately $-40{ }^{\circ} \mathrm{C}$ before refueling [6]. On average, compression processes consume $11.3 \%$ of the energy contained in hydrogen fuel [7] and are thus viewed as the most costly part of hydrogen infrastructure. Compression and storage compromise approximately $75 \%$ of the hydrogen compression, storage, and dispensing (CSD) costs for the pipeline delivery of hydrogen and forecourt hydrogen production [8]. Improving the efficiency and reducing the power consumption of compressors at hydrogen refueling stations can play significant roles in decreasing the final costs of hydrogen production [8].

Liquid piston compressor is a reliable approach in this regard. Substituting the solid piston with liquid can address many of the restrictions faced by most conventional reciprocating compressors, such as reducing several of the moving parts, simpler sealing system, the possibility of having a non-cylindrical working chamber and geometry optimization to extract heat from the gas by the liquid during the compression procedure [9]. All of these advantages may decrease the production cost and result in more efficient compressors with longer life spans [10]. A significant improvement in efficiency and a $50 \%$ reduction in cost compared with a traditional hydrogen compressor with the same flow rate and compression ratio has been reported for a single prototype unit that uses hydraulic oil to compress hydrogen [11]. However, selecting the appropriate liquid is a fundamental choice in this regard. Some liquids may decompose at elevated temperature, as reported previously for hydraulic oils [11].

Ionic liquids with outstanding properties, such as being liquid at room temperature, negligible vapor pressure together with good lubrication properties, high temperature stability, high chemical stability, low compressibility and low solubility of gasses, have attracted the attention of many engineers for use as a promising performance fluid in hydraulic and pneumatic applications [12]. Substituting lubrication oil with ionic liquid in pumps and compressors [12,13], substituting water with ionic liquid for lubrication operating in liquid ring compressor [14] and vacuum pumps [15], and finally substituting hydraulic oil with an appropriate ionic liquid in a diaphragm pump [15] are some examples of ionic 
67 liquids operating in hydraulic and pneumatic applications. These options will lead to fewer mechanical 68 losses and, ultimately, efficiency improvements [12,15].

69 In all of the above mentioned applications, corrosion is an important factor that should be considered 70 when selecting a suitable combination of ionic liquids and construction materials to avoid serious problems such as reduced efficiency, leakage of explosive gases, reduced strength, contamination of the produced products, and costly maintenance. Incorrect choices of either the ionic liquid or construction material may result in severe corrosion problems, even at ambient temperature. Serious corrosion problems in copper, aluminum and carbon steel have been observed in corrosion studies of these metals and alloys in several imidazolium- and pyrrolidinium-based ionic liquids at $25{ }^{\circ} \mathrm{C}$ [16]. In another study, the corrosion behaviors of stainless steel 316 and carbon steel 1018 were investigated in four different imidazolium-based ionic liquids for solar collectors at ambient temperature. The results showed active/passive behavior and outstanding corrosion resistance in ionic liquids, except in those that contained a chloride anion [17]. Additionally, the pitting corrosion of AISI and severe corrosion of copper in an aluminum chloride/1-ethyl-3-methylimidazolium chloride ionic liquid have been reported at ambient temperature [18]. A similar study showed an outstanding corrosion resistance of 304 SS and severe corrosion behavior of titanium in this ionic liquid [19].

In hydraulic and pneumatic industries, an increase in the operating fluid temperature due to several reasons, such as high frequencies, friction and heat absorption from other media in the system, may happen. Consequently, additional attention must be paid to the corrosion behavior of engineering alloys in ionic liquids at elevated temperatures.

The corrosion behavior of copper, nickel, AISI 1018 steel, brass, Inconel 600 in 1-butyl-3methylimidazolium bis (trifluoromethanesulfonyl) imide at elevated temperatures based on the potentiodynamic polarizations for vessels and pipes that are applicable in solar power plants showed the fundamental role that temperature plays in the corrosion rate [20]. In another study, the corrosion resistance of austenitic stainless steel, carbon steel, nickel-based alloy $\mathrm{C} 22$, brass, copper and aluminum alloy $\left(\mathrm{AlMg}_{3}\right)$ was investigated using the rotating cage method in seven different imidazolium- and ammonium-based ionic liquids up to $90{ }^{\circ} \mathrm{C}$ [21]. Stainless steel 304 showed the highest corrosion resistance in water-free and water-diluted ionic liquids at ambient and elevated temperatures, whereas brass and copper faced severe corrosion problems in the studied ionic liquids [21]. Further, the corrosion behavior of mild steel was evaluated as a function of the alkyl chain length in the cation of 1-alkyl-3-methylimidazolium tricyanomethanide $\left(\left[\mathrm{C}_{\mathrm{n}} \mathrm{mim}\right] \mathrm{TCM}, \mathrm{n}=2,4,6\right)$ ionic liquids for $\mathrm{CO}_{2}$ capture applications. The immersion test was used at $70{ }^{\circ} \mathrm{C}$ and $80{ }^{\circ} \mathrm{C}$, and the results showed that the rate of corrosion decreased with an increase in the cation alkyl chain length [22]. Furthermore, the surface corrosion of different materials (Inconel, bronze, and carbon steel) was studied in 1-butyl-3-methylimidazolium bis (trifluoromethylsulfonyl) imide after a 20-day immersion test at $225{ }^{\circ} \mathrm{C}$. The result showed the formation of corrosion layers was due primarily to the 
103

104

105

106

107

108

109

110

111

112

113

114

115

116

117

118

119

120

121

122

123

124

125

126

127

128

129

130

131

decomposition product of ionic liquids. However, absorption of decomposed products on the surface of alloys restrained the surface corrosion [23].

Although several previous studies have investigated the corrosion behavior of alloys in ionic liquids for different applications, none of them have studied the application of ionic liquids in pneumatic and hydraulic industries at elevated temperatures. This is the basis of this study, which is new, and is the contribution of the present investigation. In the present work, we studied the compatibility of alloys as construction materials in ionic liquid hydrogen compressor at $80{ }^{\circ} \mathrm{C}$. The corrosion behavior of alloys that are in contact with ionic liquids was investigated, and the role of parameters, such as temperature, viscosity, ionic liquid cation and anion, and ionic liquid water absorption, were discussed in detail.

\section{Experimental Part}

\section{Materials and electrode preparation}

We have used the five following ionic liquids (provided by Iolitec [24]) in our study:

1-Ethyl-3-methylimidazolium triflate ([EMIM] $\left.\left[\mathrm{CF}_{3} \mathrm{SO}_{3}\right]\right)$

1-Ethyl-3-methylimidazolium bis (trifluoromethylsulfonyl) imide ([EMIM] $\left[\mathrm{Tf}_{2} \mathrm{~N}\right]$ )

trihexyltetradecylphosphonium bis (trifluoromethylsulfonyl) imide $\left(\left[\mathrm{P}_{66614}\right]\left[\mathrm{Tf}_{2} \mathrm{~N}\right]\right)$

butyltrimethylammonium bis (trifluoromethylsulfonyl) imide $\left(\left[\mathrm{N}_{1114}\right]\left[\mathrm{Tf}_{2} \mathrm{~N}\right]\right)$

methyltrioctylammonium bis (trifluoromethylsulfonyl) imide $\left(\left[\mathrm{N}_{1888}\right]\left[\mathrm{Tf}_{2} \mathrm{~N}\right]\right)$

The ionic liquids were specifically selected based on certain criteria, such as high thermal and chemical stability, low compressibility, low hydrogen solubility, desired viscosity, and appropriate lubricating properties. The three selected ionic liquids with significantly lower viscosities at $25{ }^{\circ} \mathrm{C}$, which are shown in Table 2 ([EMIM] $\left.\left.\left[\mathrm{CF}_{3} \mathrm{SO}_{3}\right],[\mathrm{EMIM}]\left[\mathrm{Tf}_{2} \mathrm{~N}\right]\right),\left[\mathrm{N}_{1114}\right]\left[\mathrm{Tf}_{2} \mathrm{~N}\right]\right)$, can be used as replacements for a solid piston in reciprocating compressors, whereas the other two $\left(\left[\mathrm{P}_{66614}\right]\left[\mathrm{Tf}_{2} \mathrm{~N}\right]\right.$ and $\left.\left[\mathrm{N}_{1888}\right]\left[\mathrm{Tf}_{2} \mathrm{~N}\right]\right)$ may be more applicable for lubrication purposes. However, the presented ionic liquids and recommended construction material are not limited to ionic liquid hydrogen compressor but can be used for other hydraulic and pneumatic applications such as pumps and compressors for which heat absorption and temperature enhancement of ionic liquids may be of concern. The information regarding the chemical formulae and impurities of selected ionic liquids is summarized in Table 1.

Table 1-Chemical formulae and impurities of ionic liquids provided by the manufacturer [24]

\begin{tabular}{cccccc}
\hline Ionic liquids & $\begin{array}{l}\text { Chemical } \\
\text { formulae }\end{array}$ & Impurity & $\begin{array}{c}\text { Anion } \\
\text { Impurity }\end{array}$ & $\begin{array}{c}\text { Cation } \\
\text { Impurity }\end{array}$ & Halides \\
\hline$[\mathrm{EMIM}]\left[\mathrm{CF}_{3} \mathrm{SO}_{3}\right]$ & $\mathrm{C}_{7} \mathrm{H}_{11} \mathrm{~F}_{3} \mathrm{~N}_{2} \mathrm{O}_{3} \mathrm{~S}$ & $>99 \%$ & $99.6 \%$ & $99.1 \%$ & $<100 \mathrm{ppm}$ \\
{$[\mathrm{EMIM}]\left[\mathrm{Tf}_{2} \mathrm{~N}\right]$} & $\mathrm{C}_{8} \mathrm{H}_{11} \mathrm{~F}_{6} \mathrm{~N}_{3} \mathrm{O}_{4} \mathrm{~S}_{2}$ & $>99 \%$ & $99.9 \%$ & $99.9 \%$ & $<100 \mathrm{ppm}$ \\
{$\left[\mathrm{P}_{66614}\right]\left[\mathrm{Tf}_{2} \mathrm{~N}\right]$} & $\mathrm{C}_{34} \mathrm{H}_{68} \mathrm{~F}_{6} \mathrm{NO}_{4} \mathrm{PS}_{2}$ & $>98 \%$ & $>98 \%$ & $>98 \%$ & --- \\
{$\left[\mathrm{N}_{1114}\right]\left[\mathrm{Tf}_{2} \mathrm{~N}\right]$} & $\mathrm{C}_{9} \mathrm{H}_{18} \mathrm{~F}_{6} \mathrm{~N}_{2} \mathrm{O}_{4} \mathrm{~S}_{2}$ & $>99 \%$ & $99.9 \%$ & $99.8 \%$ & $<100 \mathrm{ppm}$ \\
{$\left[\mathrm{N}_{1888}\right]\left[\mathrm{Tf}_{2} \mathrm{~N}\right]$} & $\mathrm{C}_{27} \mathrm{H}_{54} \mathrm{~F}_{6} \mathrm{~N}_{2} \mathrm{O}_{4} \mathrm{~S}_{2}$ & $>99 \%$ & $>99 \%$ & $>99 \%$ & $<100 \mathrm{ppm}$ \\
\hline
\end{tabular}


137

138

139

140

141

142

143

144

145

146

147

148

149

150

151

152

\begin{tabular}{|c|c|c|c|c|c|c|c|c|c|c|c|c|c|}
\hline \multicolumn{14}{|c|}{ Elements, weight \% } \\
\hline Alloy type & $\mathrm{Ni}$ & $\mathrm{Ti}$ & Mo & $\mathrm{Nb}+\mathrm{Ta}$ & $\mathrm{Fe}$ & $\mathrm{Mn}$ & Al & $\mathrm{Cr}$ & Co & Si & C & $\mathbf{W}$ & Other \\
\hline AISI 316L & $10-13$ & 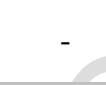 & $2-2.5$ & - & Bal. & 2.0 & - & $16.5-18.5$ & - & 1.0 & 0.03 & - & $\begin{array}{c}N \text { Less } \\
0.11\end{array}$ \\
\hline AISI 321 & $9-12$ & $0.4-0.7$ & - & - & Bal. & 2.0 & - & $17-19$ & - & 1.0 & 0.08 & - & - \\
\hline AISI 347 & $9-13$ & $\Rightarrow$ & - & 0.8 & Bal. & 2.0 & - & $17-19$ & - & 1.0 & 0.08 & - & - \\
\hline $\begin{array}{c}\text { Inconel }^{\circledR} \\
625\end{array}$ & 62 & 0.4 & 9.0 & 3.5 & 5.0 & 0.5 & 0.4 & 21.5 & 1.0 & 0.5 & 0.1 & - & - \\
\hline $\begin{array}{c}\text { Hastelloy }^{\circledR} \\
\text { C-276 }\end{array}$ & 57 & - & 16 & - & 5.5 & 1.0 & - & 15.5 & 2.5 & 0.08 & 0.02 & 3.75 & V 0.35 \\
\hline
\end{tabular}

Table 2 shows the dynamic viscosity of the tested ionic liquids at $25{ }^{\circ} \mathrm{C}$ and $80{ }^{\circ} \mathrm{C}$ and at atmospheric pressure.

Table 2- Dynamic viscosity of the tested ionic liquids at $25^{\circ} \mathrm{C}$ and $80^{\circ} \mathrm{C}$ and atmospheric pressure

\section{Dynamic viscosity (cp)}

\begin{tabular}{ccc}
\hline lonic liquids & $\mathbf{2 5}{ }^{\circ} \mathrm{C}$ & $\mathbf{8 0}{ }^{\circ} \mathrm{C}$ \\
{$[\mathrm{EMIM}]\left[\mathrm{CF}_{3} \mathrm{SO}_{3}\right]$} & $40[24]$ & $9.84 \pm 0.11[25]$ \\
{$[\mathrm{EMIM}]\left[\mathrm{Tf}_{2} \mathbf{N}\right]$} & $32[24]$ & $7.83 \pm 0.2[26]$ \\
{$\left[\mathrm{P}_{66614}\right]\left[\mathrm{Tf}_{2} \mathbf{N}\right]$} & $304[24]$ & $14.1[27]$ \\
{$\left[\mathrm{N}_{1114}\right]\left[\mathrm{Tf}_{2} \mathrm{~N}\right]$} & $99[24]$ & $14.7 \pm 0.2[28]$ \\
{$\left[\mathrm{N}_{1888}\right]\left[\mathrm{Tf}_{2} \mathbf{N}\right]$} & $530[24]$ & $30.8^{*}[29]$
\end{tabular}

* predicted viscosity based on third-degree polynomial curve fitting of dynamic viscosity data for the temperature range of 20 $60{ }^{\circ} \mathrm{C}$, as presented in $[29]$

The ionic liquids that served as electrolytes in the working compartment of the electrochemical cell were tested in contact with the following austenitic stainless steels and nickel-based alloys.

Austenitic stainless steels: AISI 316L, AISI 321, and AISI 347

Nickel-based alloys: Inconel ${ }^{\circledR} 625$ and Hastelloy ${ }^{\circledR} \mathrm{C}-276$

All of the alloys that served as working electrodes were provided as wires by Sigma Aerospace Metals [30]. The diameter of the wires was in the range of 0.8 to $1 \mathrm{~mm}$. The typical chemical composition of austenitic stainless steels and nickel-based alloys, which were studied in this work, is presented in Table 3. To determine the surface area of the working electrodes, all wires were sealed in alumina tubes with inner and outer diameters of 2 and $4 \mathrm{~mm}$, respectively. A coating paste CC189W, which was provided by CeProTec [31], was used to seal the electrodes inside the tubes. The geometrical working electrode area of all of the tested alloys was limited to between 8 and $20 \mathrm{~mm}^{2}$.

Table 3 - Chemical composition of the alloys

Elements, weight \%

153 
A platinum wire of $0.4 \mathrm{~mm}$ in diameter, provided by Dansk Aedelmetal A/S [32], was used as a counter electrode. A silver wire of $0.5 \mathrm{~mm}$ in diameter, also provided by Dansk Aedelmetal A/S [32], was used as a reference electrode. The ionic liquid $\left[\mathrm{N}_{1114}\right]\left[\mathrm{Tf}_{2} \mathrm{~N}\right]$ saturated with $\mathrm{Ag}_{2} \mathrm{SO}_{4}$ (with 99\% purity provided by Heraeus [33]) was used as an electrolyte for the reference electrode compartment in all of the experiments. The reliability of this reference electrode has been previously reported [34,35]. The potential of the $\mathrm{Ag} / \mathrm{Ag}_{2} \mathrm{SO}_{4}$ electrode is approximately $0.7 \mathrm{~V}$ more positive than of the standard hydrogen electrode [36] at room temperature.

\section{Gravimetric method and scanning electron microscopy}

Five samples of each alloy were prepared as thin cylindrical discs that were cut from the tested alloy wires, and their faces were grinded with a P1200 grit silicon carbide paper (provided by Struers [37]) to achieve a reproducible surface finish. Then, the samples were washed with acetone to remove any polishing residue, dried in the oven, and weighed using an analytical balance with an accuracy of 0.01 mg. The weighted samples were placed in small Pyrex vessels filled with ionic liquids and placed in the furnace at $80{ }^{\circ} \mathrm{C}$. After 120 hours of immersion, the samples were rinsed with acetone, dried in a furnace, and finally weighed again at room temperature.

To obtain more information about the corrosion behavior of the tested alloys, cross-sections of the samples after the immersion test were studied using scanning electron microscopy (SEM). All samples were mounted in PolyFast phenolic hot mounting resin with a carbon filler, provided by Struers [37]. SEM measurements were made using a Zeiss EVO MA10 scanning electron microscope.

\section{Electrochemical Corrosion Cell}

The corrosion test was performed in an electrochemical cell with a special design that was built in our laboratory. The cell (shown in Figure 1) represented a typical three-electrode configuration that consisted of the working, counter and reference electrodes. The two working and reference compartments were separated with a porous frit, which is shown as Position 6, Figure 1. The counter electrode (Position 4 in Figure 1) was placed in the same compartment where the working electrode was located. The spiral form of the counter and reference electrodes (platinum and silver wires) ensured a high surface area.

For the measurements at $80^{\circ} \mathrm{C}$, the cell was immersed in the temperature-controlled water bath. A Chromel-Alumel PFA coated thermocouple, which was provided by Omega [38], was used to measure the temperature inside the electrochemical cell. The thermocouple (Position 3 in Figure 1) was located in the same compartment with the working electrode. A temperature tolerance of $\pm 3{ }^{\circ} \mathrm{C}$ was allowed during the experiment.

A potentiostat model VersaSTAT 3 with the VersaStudio software by Princeton Applied research [39] was used for the electrochemical measurements. Once the open-circuit potential was established, the 
steady-state cyclic voltammetry technique with a scan rate of $5 \mathrm{mV} / \mathrm{s}$ was performed. The potential window was $2 \mathrm{~V}$, starting at $-1 \mathrm{~V}$, then going to $1 \mathrm{~V}$ and ending at $-1 \mathrm{~V}$, all against the reference electrode potential.

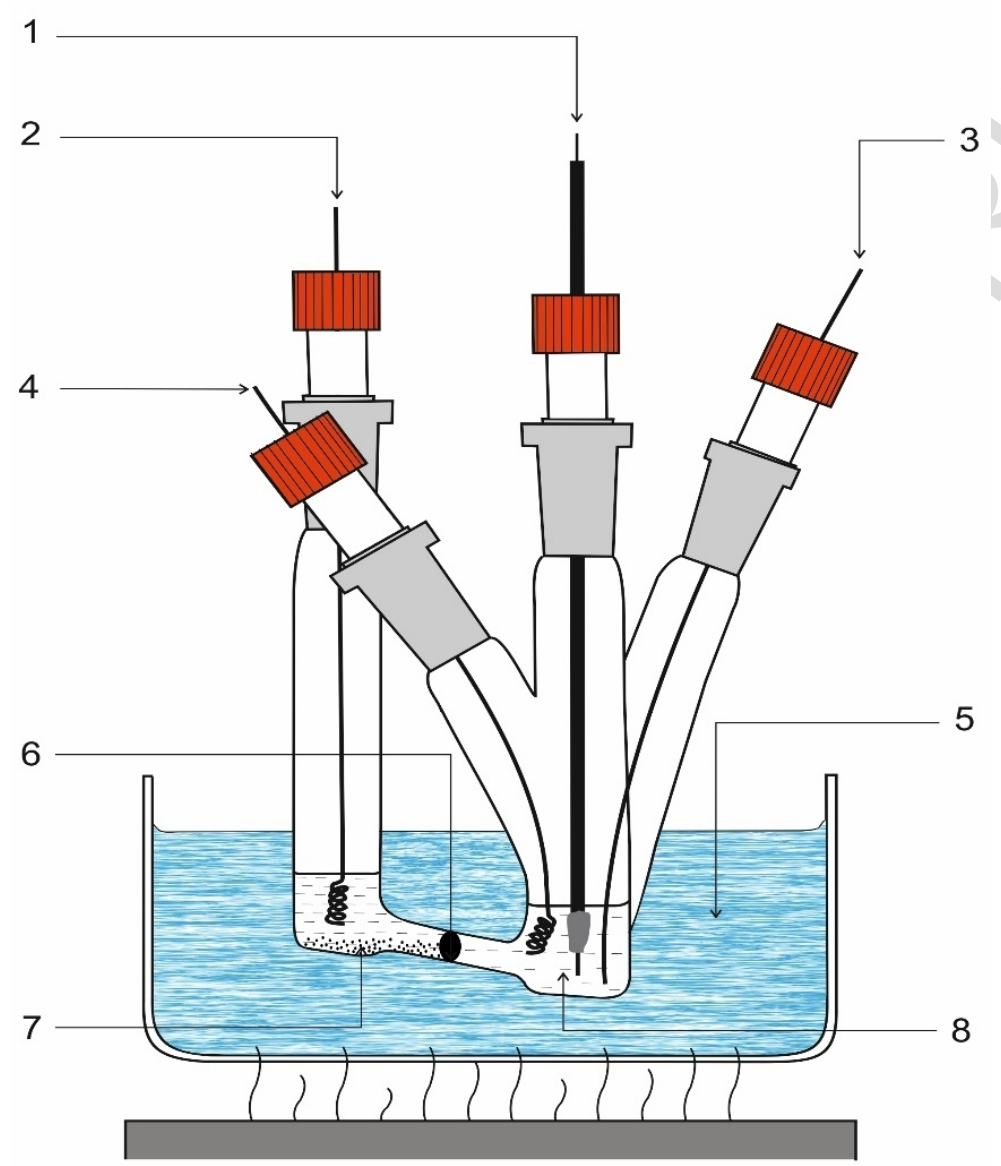

Figure 1 - Electrochemical cell: (1) Working electrode; (2) Reference electrode (Ag wire); (3) Thermocouple; (4) Counter electrode (Pt wire); (5) Hot water bath; (6) Porous frit; (7) Saturated $\mathrm{Ag}_{2} \mathrm{SO}_{4}$; (8) Electrolyte (ionic liquids)

\section{Results and discussion}

\section{Immersion test}

After 5 days of immersion, neither serious damage on the surface of the alloy samples nor any considerable changes in the color of ionic liquids were observed. Table 4 shows the amount of changes in the weight of alloy samples after 120 hours of immersion in the tested ionic liquids at $80{ }^{\circ} \mathrm{C}$. Other than a slight increase in weight, no significant changes were detected using an analytical balance. The formation of an oxide layer around the samples, as a known factor reported in many corrosion studies [40,41], explains the slight increase in the samples' weight. Figure 2 shows SEM images of the 
stainless steel alloy AISI 347 after 120 hours of immersion in [EMIM] $\left[\mathrm{CF}_{3} \mathrm{SO}_{3}\right]$ at $80{ }^{\circ} \mathrm{C}$, with the highest weight gain percentage. The formation of thin oxide layer on the sample surface can be observed in Figure 2.

Table 4-Amount of weight gain and weight gain percentage of stainless steels and nickel-based alloy samples, after 120 hours of immersion in the tested ionic liquids at $80^{\circ} \mathrm{C}$ gain weight, $10^{-5} \mathrm{gr}$ (weight gain percentage *)

\begin{tabular}{|c|c|c|c|c|c|}
\hline & {$[\mathrm{EMIM}]\left[\mathrm{CF}_{3} \mathrm{SO}_{3}\right]$} & {$[E M I M]\left[\mathrm{Tf}_{2} \mathrm{~N}\right]$} & {$\left[P_{66614}\right]\left[\mathrm{Tf}_{2} \mathrm{~N}\right]$} & {$\left[\mathrm{N}_{1114}\right]\left[\mathrm{Tf}_{2} \mathrm{~N}\right]$} & {$\left[N_{1888}\right]\left[T_{2} N\right]$} \\
\hline AISI 316L & 34 (0.77\%) & 4 (0.1\%) & 7 (0.24\%) & $6(0.24 \%)$ & $6(0.2 \%)$ \\
\hline AISI 321 & $8(0.19 \%)$ & $2(0.04 \%)$ & $23(0.55 \%)$ & $5(0.15 \%)$ & $1(0.02 \%)$ \\
\hline AISI 347 & $27(0.78 \%)$ & $9(0.34 \%)$ & $9(0.37 \%)$ & $3(0.13 \%)$ & $4(0.17 \%)$ \\
\hline Inconel ${ }^{\circledR} 625$ & $14(0.33 \%)$ & $12(0.27 \%)$ & $21(0.64 \%)$ & $16(0.54 \%)$ & $4(0.13 \%)$ \\
\hline Hastelloy ${ }^{\circledR}$ C-276 & $10(0.34 \%)$ & $4(0.14 \%)$ & $8(0.29 \%)$ & $1(0.05 \%)$ & $10(0.46 \%)$ \\
\hline
\end{tabular}

*Weight gain percentage is calculated based on ((weight after immersion - weight before immersion)/ weight before immersion) $* 100$

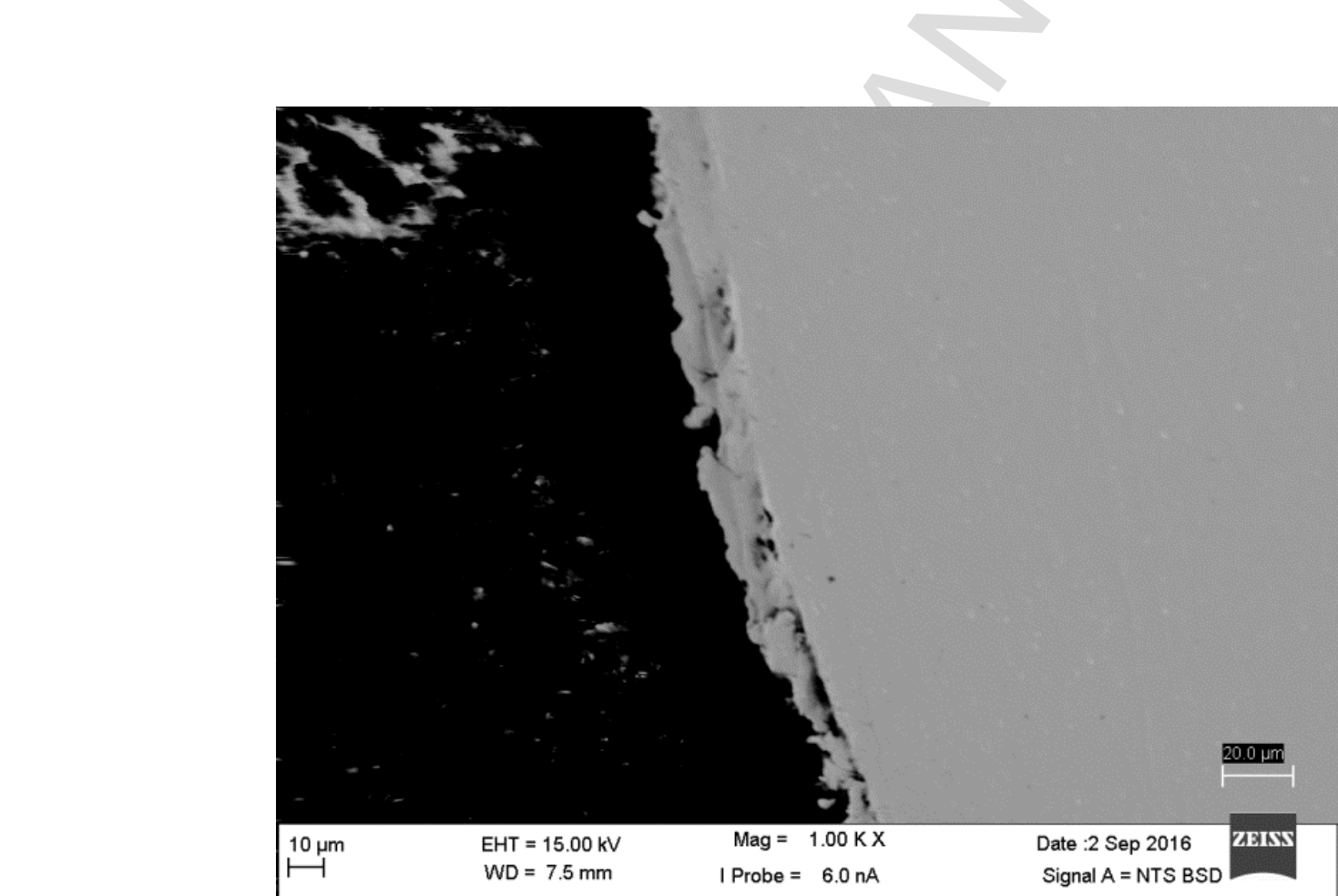

Figure 2 -SEM of the cross-section of the AISI 347 sample after 120 hours of immersion in $[\mathrm{EMIM}]\left[\mathrm{CF}_{3} \mathrm{SO}_{3}\right]$ at $80^{\circ} \mathrm{C}$

\section{Electrochemical measurements}

Figures 3-7 show Tafel plots of austenitic stainless steels and nickel-based alloys that were measured in [EMIM] $\left[\mathrm{CF}_{3} \mathrm{SO}_{3}\right],[\mathrm{EMIM}]\left[\mathrm{Tf}_{2} \mathrm{~N}\right],\left[\mathrm{P}_{66614}\right]\left[\mathrm{Tf}_{2} \mathrm{~N}\right],\left[\mathrm{N}_{1114}\right]\left[\mathrm{Tf}_{2} \mathrm{~N}\right]$, and $\left[\mathrm{N}_{1888}\right]\left[\mathrm{Tf}_{2} \mathrm{~N}\right]$ at $80{ }^{\circ} \mathrm{C}$. 


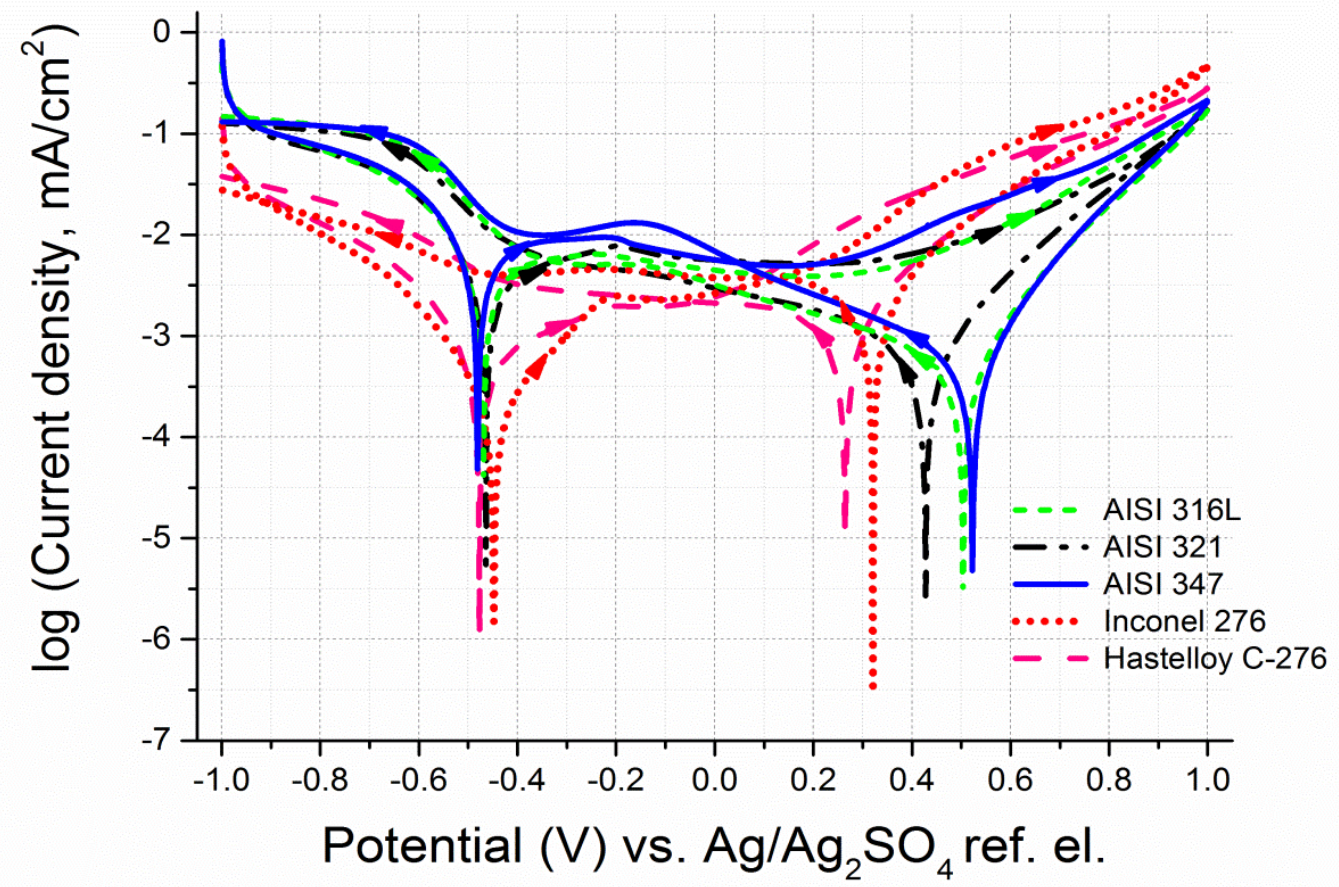

Figure 3 - Tafel plot for the tested alloys in [EMIM] $\left[\mathrm{CF}_{3} \mathrm{SO}_{3}\right]$ at $80^{\circ} \mathrm{C}$

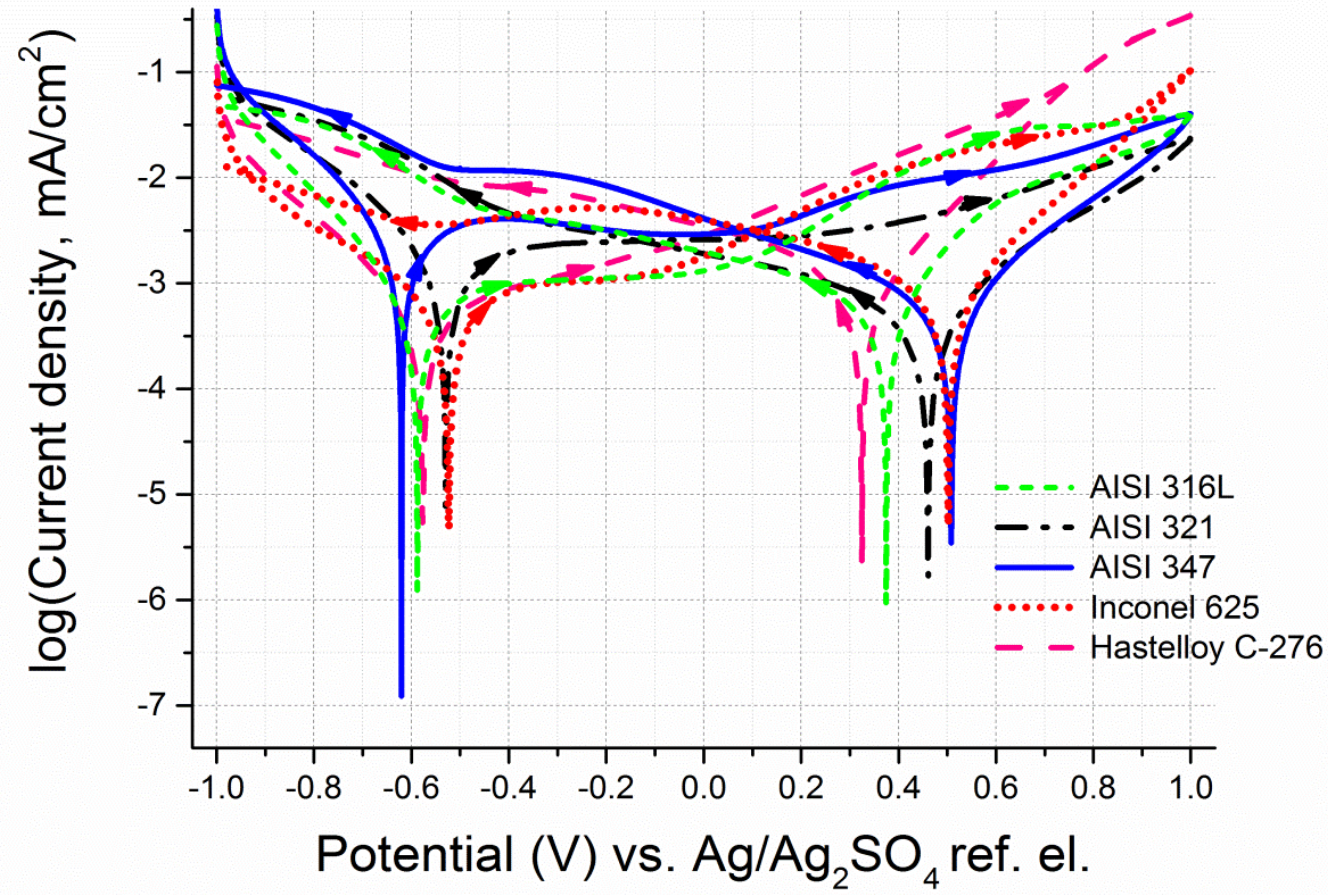

Figure 4 - Tafel plot for the tested alloys in [EMIM][Tf $\left.{ }_{2} \mathrm{~N}\right]$ at $80^{\circ} \mathrm{C}$ 


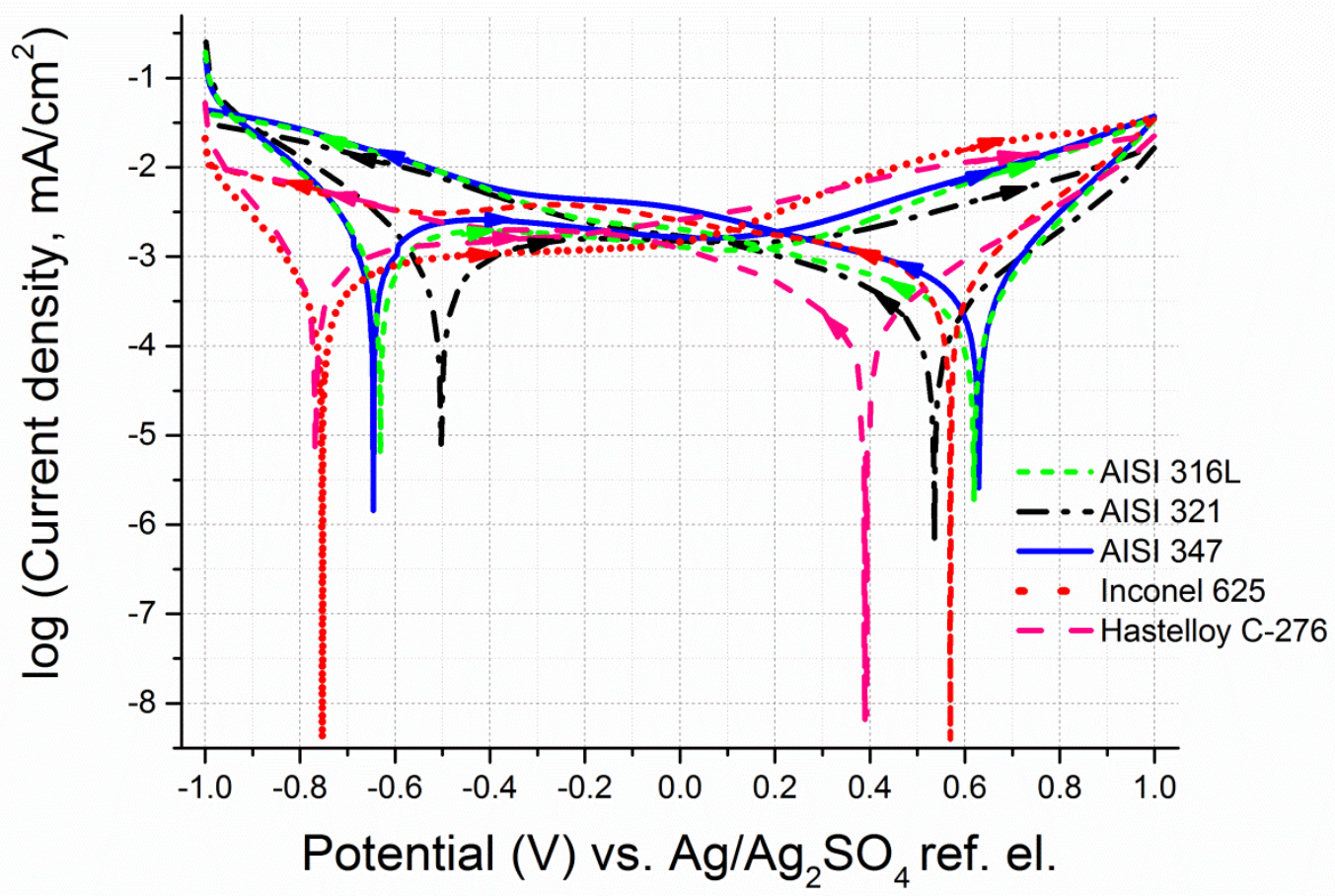

Figure 5 - Tafel plot for the tested alloys in $\left[P_{66614}\right]\left[T f_{2} N\right]$ at $80^{\circ} \mathrm{C}$

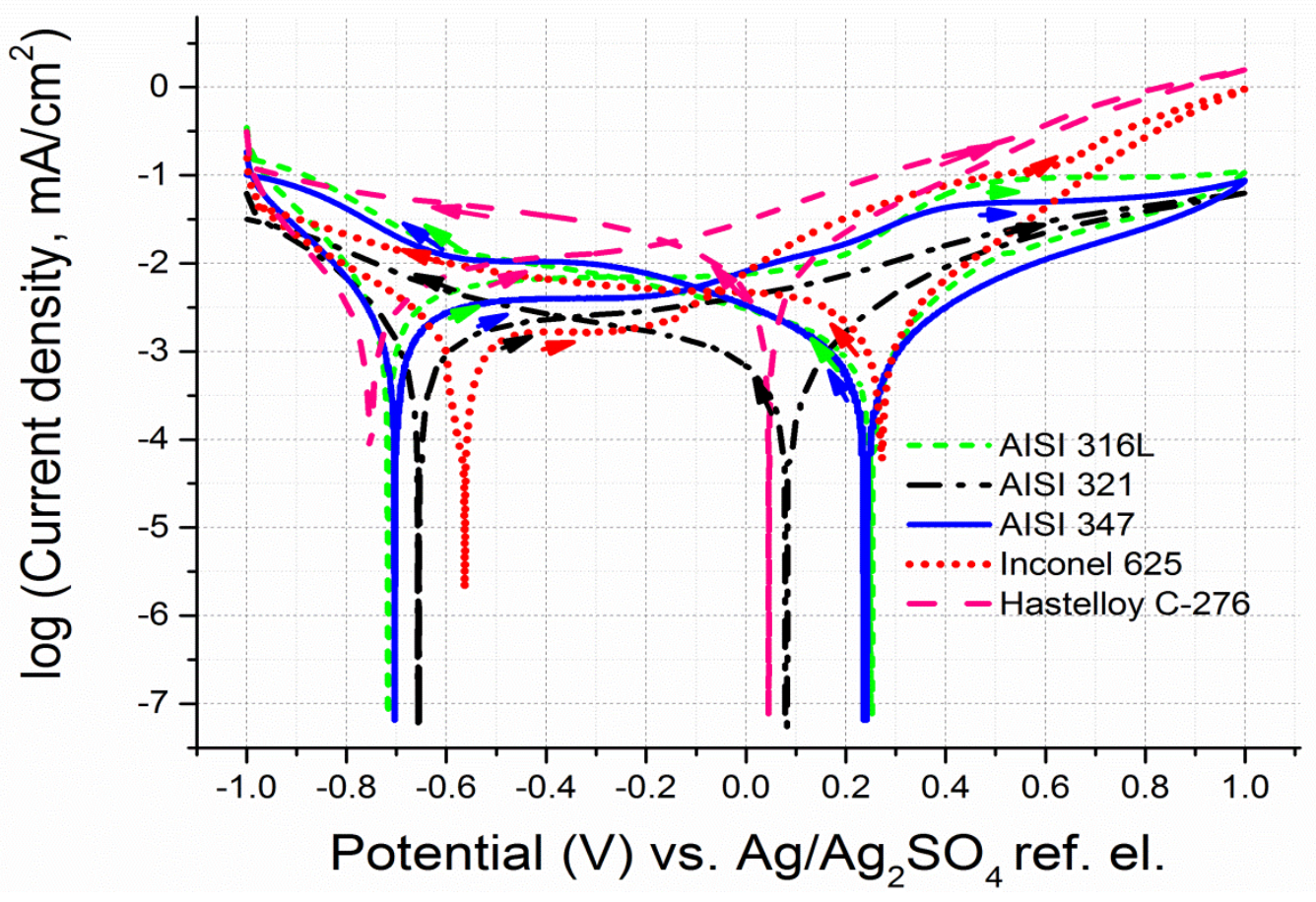

Figure 6 - Tafel plot for the tested alloys in $\left[N_{1114}\right]\left[\mathrm{Tf}_{2} \mathrm{~N}\right]$ at $80^{\circ} \mathrm{C}$ 


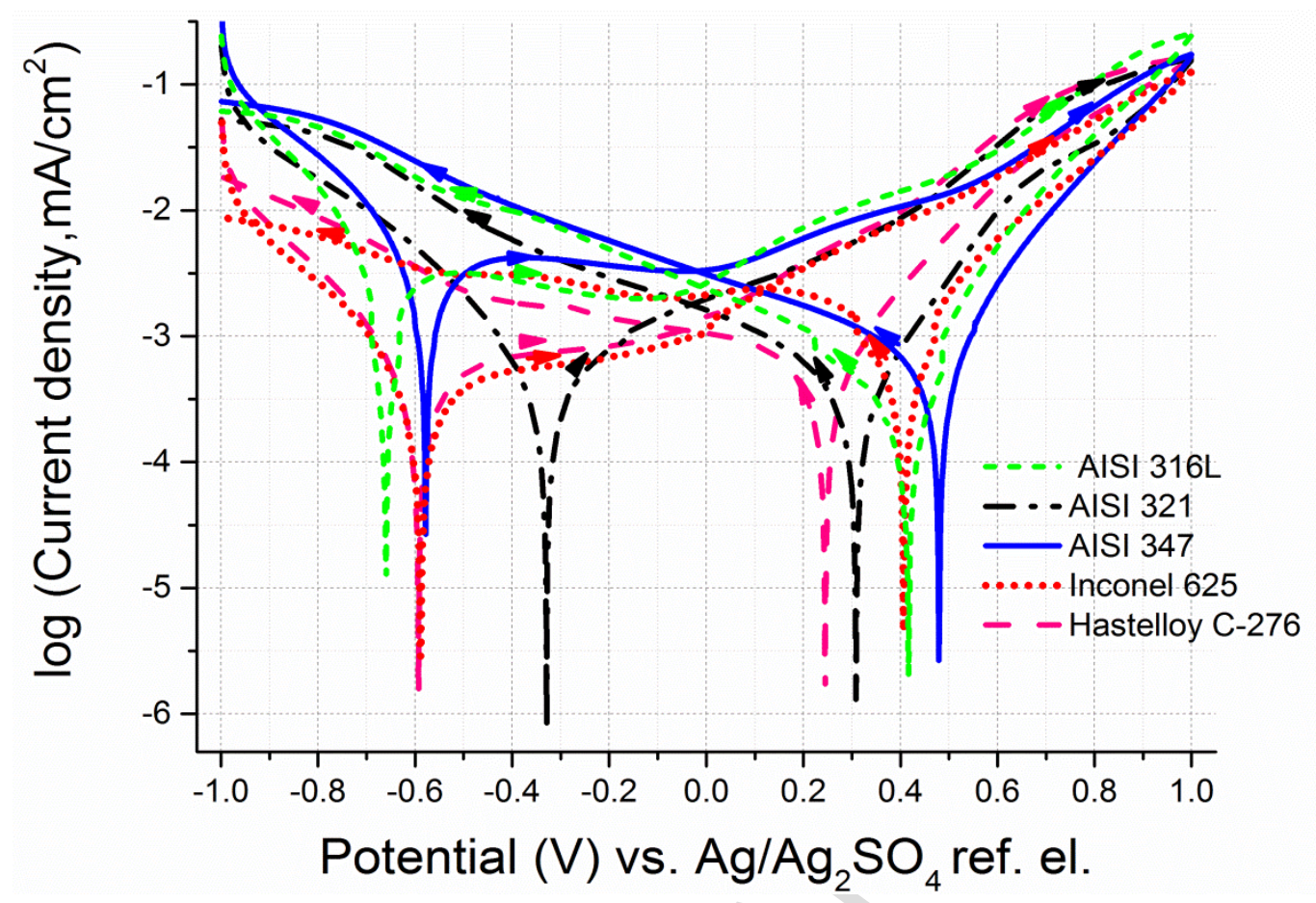

Figure 7 - Tafel plot for the tested alloys in $\left[\mathrm{N}_{1888}\right]\left[\mathrm{Tf}_{2} \mathrm{~N}\right]$ at $80^{\circ} \mathrm{C}$

Figures 3-7 show that by changing the direction of polarization from anodic to cathodic, the current values of the reverse voltametric curves are reduced in high anodic region close to $1 \mathrm{~V}$ vs. the reference electrode. This fact indicates the passivation of almost all of the electrodes in this region with the metal oxide layer at $80{ }^{\circ} \mathrm{C}$. However, further investigation is required to better understand the nature of the passive layer.

Table 5 presents the estimated corrosion current densities of all tested alloys in the five studied electrolytes. The intersection point of the vertical line through corrosion potential and the extrapolated linear portions of the anodic and cathodic polarizations in Tafel plots can be used to estimate the value of the corrosion current density $\left(i_{\text {corr }}\right)[42,43]$. 
Table 5 - Corrosion current densities for the stainless steels and nickel-based alloys in the tested ionic liquids at $80^{\circ} \mathrm{C}$ $\mathrm{i}_{\mathrm{corr}}\left(10^{-5} \mathrm{~mA} / \mathrm{cm}^{2}\right)$

$[E M I M]\left[\mathrm{CF}_{3} \mathrm{SO}_{3}\right] \quad[\mathrm{EMIM}]\left[\mathrm{Tf}_{2} \mathrm{~N}\right] \quad\left[\mathrm{P}_{66614}\right]\left[\mathrm{Tf}_{2} \mathrm{~N}\right] \quad\left[\mathrm{N}_{1114}\right]\left[\mathrm{Tf}_{2} \mathrm{~N}\right] \quad\left[\mathrm{N}_{1888}\right]\left[\mathrm{Tf}_{2} \mathrm{~N}\right]$

\begin{tabular}{cccccc} 
AISI $316 \mathrm{~L}$ & 4 & 5 & 2 & 6.3 & 3.2 \\
AISI 321 & 5 & 3.5 & 2 & 5.6 & 5 \\
AISI 347 & 5 & 4 & 3.2 & 10 & 6 \\
Inconel $^{\circledR} 625$ & 20 & 8 & 8 & 25 & 8 \\
Hastelloy $^{\circledR}$ C-276 & 10 & 6.3 & 1.3 & 31.6 & 4 \\
\hline
\end{tabular}

Although a considerable increase in the corrosion rate can be expected at elevated temperatures, the corrosion current density values, as estimated from the Tafel plots (shown in Table 5), were very low, which indicates a small corrosion rate for all of the alloys in any of the five tested ionic liquids at 80 ${ }^{\circ} \mathrm{C}$. It can be seen from Table 5 that even in the worst case (Hastelloy® $\mathrm{C}-276$ in $\left[\mathrm{N}_{1114}\right]\left[\mathrm{Tf}_{2} \mathrm{~N}\right]$ with $\mathrm{i}_{\text {corr }}=31.6 \times 10^{-5} \mathrm{~mA} / \mathrm{cm}^{2}$ ), the corrosion current density value is very low and is comparable to the corrosion current density and corrosion rate values for one of the most corrosion-stable metals in an aggressive solution of hot phosphoric acid (tantalum $\mathrm{i}_{\text {corr }}=31.5 \times 10^{-5} \mathrm{~mA} / \mathrm{cm}^{2}$ equal to corrosion rate $<$ $1 \mu \mathrm{m} /$ year) [44]. In general, materials can be considered outstanding corrosion-resistant materials when the corrosion rate is less than $20 \mu \mathrm{m} /$ year [45]. Consequently, a primary evaluation of the results shows that all of the alloys tested in this study can be safely used as construction materials for all of the components in direct contact with the five ionic liquids tested at elevated temperatures and up to $80{ }^{\circ} \mathrm{C}$. Table 6 shows the ratio of corrosion current densities of the stainless steels and nickel-based alloys in the tested ionic liquids at $80{ }^{\circ} \mathrm{C}$ compared with $23^{\circ} \mathrm{C}[46]$.

Table 6-Ratio of the corrosion current densities at $80{ }^{\circ} \mathrm{C}$ to Corrosion current densities at $23{ }^{\circ} \mathrm{C}$ [46] for the stainless steels and nickel-based alloys in the ionic liquids tested

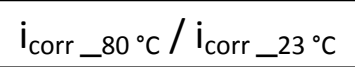

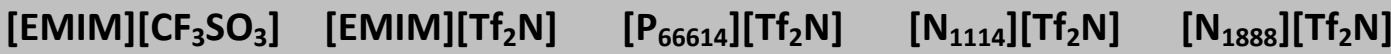

\begin{tabular}{cccccc} 
AISI 316L & 5 & 3.1 & 2.5 & 1.6 & 1.8 \\
AISI 321 & 6.2 & 3.2 & 2.5 & 1.8 & 6.2 \\
AISI 347 & 2 & 3.1 & 2.5 & 1.2 & 2.4 \\
\hline Inconel $^{\circledR} 625$ & 4 & 2 & 2.5 & 1.6 & 1.6 \\
\hline Hastelloy $^{\circledR}$ C-276 & 5.6 & 3.1 & 1.3 & 3.2 & 2 \\
\hline
\end{tabular}

Table 6 shows that the rate of corrosion current densities increased at $80{ }^{\circ} \mathrm{C}$ compared with that at 23 
287

role in the corrosion current density rate increase. The viscosity will significantly decrease with an increase in temperature based on the Arrhenius equation [47]. Table 1 reports a dramatic reduction in viscosity at $80{ }^{\circ} \mathrm{C}$ compared with that at $25{ }^{\circ} \mathrm{C}$. Generally, the viscosity of an ionic liquid is an important electrochemical property, and a highly viscous medium decreases the rate of diffusioncontrolled chemical reaction [48]. In contrast, a less viscous medium has faster ion motilities in the presence of oxidant, which facilitates faster electrochemical reactions.

Table 7 presents the corrosion potentials of the stainless steels and nickel-based alloys in the tested ionic liquids at $80^{\circ} \mathrm{C}$, which are obtained from Tafel plots (Figures 3-7). The corrosion potentials of the tested alloys probably relate to the dissolution of the anodically polarized alloys, whereas the current drop at negative potentials (cathodic process) may be related to the reduction of oxygen or electrolytes. Further studies of the chemistry and electrochemistry of the tested ionic liquids are required to obtain a detailed understanding of the cathodic processes. Higher corrosion potentials will lead to lower corrosion rates of the alloy in the electrolyte, as reported previously [44].

Table 7 - Corrosion potentials of the stainless steels and nickel-based alloys in the tested ionic liquids at $80^{\circ} \mathrm{C}$

$$
\mathrm{E}_{\text {corr }}, \mathrm{mV}\left(\mathrm{vs} \mathrm{Ag} / \mathrm{Ag}_{2} \mathrm{SO}_{4}\right)
$$

\begin{tabular}{|c|c|c|c|c|c|}
\hline & [EMIM] $\left[\mathrm{CF}_{3} \mathrm{SO}_{3}\right]$ & {$[\mathrm{EMIM}]\left[\mathrm{Tf}_{2} \mathrm{~N}\right]$} & {$\left[P_{66614}\right]\left[T_{2} N\right]$} & {$\left[N_{1114}\right]\left[T f_{2} N\right]$} & {$\left[\mathrm{N}_{1888}\right]\left[\mathrm{Tf}_{2} \mathrm{~N}\right]$} \\
\hline AISI 316L & 503 & 374 & 620 & 252 & 417 \\
\hline AISI 321 & 428 & 461 & 536 & 83 & 309 \\
\hline AISI 347 & 522 & 508 & 629 & 242 & 479 \\
\hline Inconel ${ }^{\circledR} 625$ & 321 & 502 & 569 & 272 & 407 \\
\hline Hastelloy ${ }^{\circledR}$ C-276 & 265 & 324 & 394 & 45 & 245 \\
\hline
\end{tabular}

A comparison of the results obtained in Table 7 at $80{ }^{\circ} \mathrm{C}$ with those reported in [46] for $23{ }^{\circ} \mathrm{C}$ shows the reduction of corrosion potentials at higher temperatures. This is consistent with an increase in corrosion current densities at $80^{\circ} \mathrm{C}$, as shown in Table 6 .

It can be seen from Table 7 that among all of the tested alloys, AISI 347 is remarkable at $80{ }^{\circ} \mathrm{C}$ because it has high corrosion potentials in all of the ionic liquids tested. The high corrosion resistance of AISI 347 at $80{ }^{\circ} \mathrm{C}$ can be attributed to the presence of approximately $0.8 \%$ niobium and tantalum in the structure of this alloy. The presence of niobium and tantalum in AISI 347 may lead to the formation of a passive layer, which reduces the dissolution rate of the alloy in the electrolyte [49].

Figure 8 shows the Tafel plot for the stainless steel alloy AISI 347 in all five ionic liquids tested. 


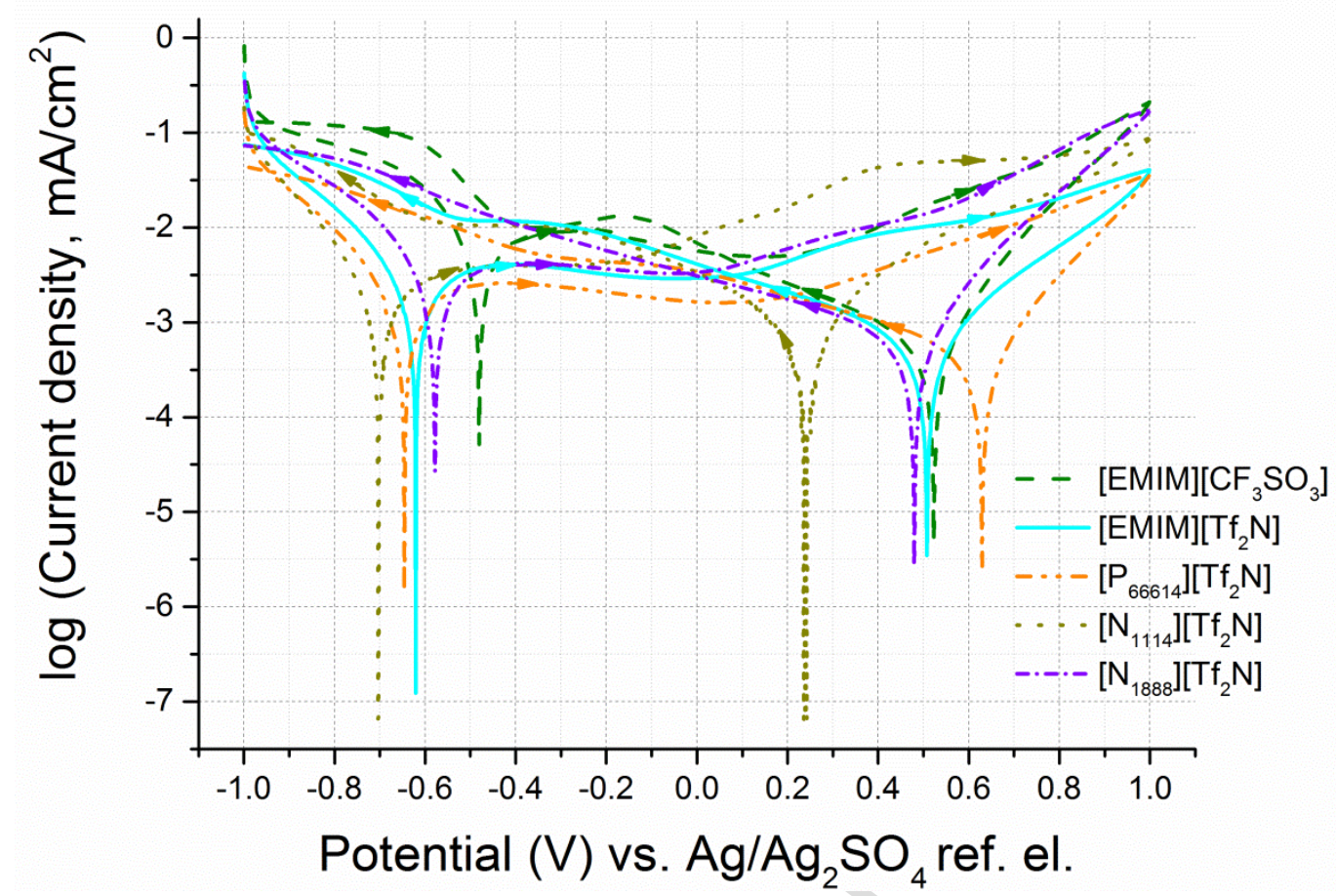

298

299

300

301

302

303

304

305

306

307

308

309

310

311

312

313

314

315

316

317

Figure 8-Tafel plot for AISI 347 in [EMIM][CF $\left.\mathrm{SO}_{3}\right]$, [EMIM][Tf $\left.\mathrm{E}_{2}\right],\left[\mathrm{P}_{66614}\right]\left[\mathrm{Tf}_{2} \mathrm{~N}\right]$, [N $\left.\mathrm{N}_{1114}\right]\left[T f_{2} \mathrm{~N}\right]$, and $\left[\mathrm{N}_{1888}\right]\left[\mathrm{Tf}_{2} \mathrm{~N}\right]$ at $80^{\circ} \mathrm{C}$.

It can be seen from Figure 8 and Tables 5 and 7 that the stainless steel alloy AISI 347 shows the highest corrosion resistance in $\left[\mathrm{P}_{66614}\right]\left[\mathrm{Tf}_{2} \mathrm{~N}\right]$, [EMIM] $\left[\mathrm{Tf}_{2} \mathrm{~N}\right]$ and $[\mathrm{EMIM}]\left[\mathrm{CF}_{3} \mathrm{SO}_{3}\right]$ ionic liquids.

In general, a comparison of the corrosion potentials of the two nickel-based alloys (Inconel® 625 and Hastelloy® C-276) with the stainless steel alloys at $80{ }^{\circ} \mathrm{C}$ shows that there is no noteworthy improvement in the corrosion rate of high nickel concentration alloys in the studied electrolytes. Table 7 shows that Hastelloy ${ }^{\circledR}$ C-276, with a nickel content above 55 wt. \%, is the least corrosion-resistant alloy at $80{ }^{\circ} \mathrm{C}$. The lack of niobium and tantalum in the structure of this alloy compared with the other nickel-based alloy Inconel ${ }^{\circledR} 625$ may play a role in the poor performance of this alloy $[49,50]$.

\section{Role of Ionic Liquid Cation and Anion}

Although AISI 347 and Hastelloy® C-276 showed a similar corrosion behavior in all of the ionic liquids tested, different corrosion behaviors were observed for AISI 316L and Inconel® 625 in different electrolytes. As can be seen in Figure 4 and Table 7, AISI 316L showed a relatively poor corrosion resistance in [EMIM] $\left[\mathrm{Tf}_{2} \mathrm{~N}\right]$ compared with the stainless steel alloys AISI 347 and AISI 321 and the nickel-based alloy Inconel ${ }^{\circledR}$ 625. In contrast, stainless steel AISI 316L was one of the most stable alloys in other electrolytes, with a relatively high corrosion resistance close to that of AISI 347. In contrast, as seen from Figure 3 and Table 7, Inconel ${ }^{\circledR}$ 625, with a relatively high corrosion resistance (comparable with AISI 347) in $[\mathrm{EMIM}]\left[\mathrm{Tf}_{2} \mathrm{~N}\right],\left[\mathrm{P}_{66614}\right]\left[\mathrm{Tf}_{2} \mathrm{~N}\right],\left[\mathrm{N}_{1114}\right]\left[\mathrm{Tf}_{2} \mathrm{~N}\right]$, and $\left[\mathrm{N}_{1888}\right]\left[\mathrm{Tf}_{2} \mathrm{~N}\right]$, showed a relatively poor corrosion resistance compared with the other alloys in 
318 [EMIM] $\left[\mathrm{CF}_{3} \mathrm{SO}_{3}\right]$. Such differences show the role of both cation and anion of ionic liquids in the

319

320

321

322

323

324

325

326

327

328

329

330

331

332

333

334

335

336

337

338

339

340

341

342

343

344

345

346

347

corrosion behavior of the tested alloys in different ionic liquid-based electrolytes. Such dependencies have also been reported previously [21].

\section{Role of Ionic Liquid water absorption}

In addition to viscosity and the nature of the cations and anions of ionic liquids, water miscibility is an important parameter in ionic liquids that can affect the corrosion behavior of alloys. Water is reported to be one of the most significant impurities in ionic liquids that can change the physical and chemical properties of ionic liquids [51-53] because even hydrophobic ionic liquids can absorb some amount of water from the atmosphere [51,54]. Water can affect the electrochemical reaction and reduce the potential window [55]. In addition, an increase in the water content in an ionic liquid has been shown to decrease viscosity [53,55-57]. Enhancing the cation and anion mobility and increasing the transport of molecular species in ionic liquids are consequences of a reduction in ionic liquid viscosity [58]. The significant role of reducing the water content in decreasing the corrosion rate has been reported [22]. To investigate the role of water content in the corrosion rate of the tested alloys, the water content of five ionic liquids studied was measured at $25{ }^{\circ} \mathrm{C}$ under atmospheric conditions using Karl Fischer Titration. The samples were used directly from the bench without any attempt for drying or purification and the results are shown in Table 8.

Table 8 - Water content of the five tested ionic liquids at $25^{\circ} \mathrm{C}$ under atmospheric conditions

\begin{tabular}{cc}
\hline Ionic Liquids & Water content (ppm) \\
\hline$[E M I M]\left[\mathrm{CF}_{3} \mathrm{SO}_{3}\right]$ & 1683 \\
{$[\mathrm{EMIM}]\left[\mathrm{Tf}_{2} \mathbf{N}\right]$} & 792 \\
{$\left[\mathrm{P}_{66614}\right]\left[\mathrm{Tf}_{2} \mathbf{N}\right]$} & 442 \\
{$\left[\mathrm{~N}_{1114}\right]\left[\mathrm{Tf}_{2} \mathrm{~N}\right]$} & 1007 \\
{$\left[\mathrm{~N}_{1888}\right]\left[\mathrm{Tf}_{2} \mathrm{~N}\right]$} & 1046 \\
\hline
\end{tabular}

It can be seen from Tables 5, 7, and 8 that all of the stainless steels and nickel-based alloys showed the best corrosion resistance behavior (the lowest corrosion current densities and the highest corrosion potentials) in $\left[\mathrm{P}_{66614}\right]\left[\mathrm{Tf}_{2} \mathrm{~N}\right]$, with a relatively high viscosity and the lowest water content compared with the other ionic liquids in this study.

Generally, as discussed above, the low corrosion current densities at $80{ }^{\circ} \mathrm{C}$ prove the possibility of selecting all of the alloys tested as construction materials for components that are in direct contact with the five ionic liquids studied in this work. However, the final choice may depend on several parameters, such as the operating temperature and pressure of the system, limitations in selecting a material for a specific application, ease of fabrication, mechanical properties, hydrogen embrittlement, and price. 


\section{Conclusion}

349 The compatibility of various austenitic stainless steels and nickel-based alloys as construction 350 materials, in contact with five different ionic liquids, selected as performance fluid in an ionic liquid 351 hydrogen compressor were studied at $80{ }^{\circ} \mathrm{C}$ and atmospheric air. The role of parameters, such as 352 temperature, viscosity, ionic liquid cation and anion, and ionic liquid water absorption, on the corrosion 353 behavior of alloys were investigated using the gravimetric test, cyclic polarization and Tafel plots. 354 Under the tested conditions, the following findings were presented:

355

356

357

358

359

360

361

362

363

364

365

366

367

368

369

370

371

372

373

374

375

376

377

\section{Acknowledgment}

379 The authors would like to thank the Innovation Fund Denmark for the financial support of this work 380

- In general, the corrosion rate increased with increasing temperature. However, very low corrosion rates of the tested alloys in the studied ionic liquids were observed. Consequently, all alloys are safe to use as construction materials for ionic liquid hydrogen compressors and/or other hydraulic and pneumatic components that are in direct contact with the studied ionic liquids at elevated temperatures up to $80^{\circ} \mathrm{C}$.

- Small weight gain of the tested alloys and SEM analysis confirmed the formation of an oxide layer after the exposure of materials to selected ionic liquids.

- A small addition of tantalum and niobium to the alloy structure can enhance the corrosion stability of alloys that were tested in the studied ionic liquid-based electrolytes at $80^{\circ} \mathrm{C}$.

- The stainless steel alloy, AISI 347, showed an outstanding corrosion stability in all five ionic liquids studied. Nevertheless, the nickel-based alloy Hastelloy ${ }^{\circledR}$ C- 276 showed the poorest corrosion resistance compared with the other tested alloys in the studied electrolytes.

- The preliminary investigation of the tested alloy behavior in the studied ionic liquid-based electrolytes proved the importance of both the cation and anion roles of ionic liquids in determining the corrosion resistance of the tested alloys.

- Reducing the viscosity and enhancing the water content of an ionic liquid can play a key role in increasing the corrosion rate. All of the studied alloys have the highest corrosion resistance in the $\left[\mathrm{P}_{66614}\right]\left[\mathrm{Tf}_{2} \mathrm{~N}\right]$ ionic liquid, with a relatively high viscosity and the lowest water content. (grant number DNF93, HyFill-Fast project), Larisa Seerup for the help with SEM, Judith Grünauer and Anna-Lisa Chaudhary for the help with water content measurements. 
382

383

384

385

386

387

388

389

390

391

392

393

394

395

396

397

398

399

400

401

402

403

404

405

406

407

408

409

410

411

412

413

414

415

416

417

418

419

\section{References}

[1] B. Müller, Fritjof Nansen Institute, The Global Climate Change Regime: Taking Stock and Looking Ahead, of International Co-operation on Environment and Development, London, 2002.

[2] International Energy Agency, $2012 \mathrm{CO} 2$ emissions overview, $\mathrm{CO} 2$ Emiss. from Fuel Combust. (2014) 1-12.

[3] E. Nederhoff, Transport Energy and CO2 : Moving towards Sustainability - Books - OECD iLibrary, 2009. doi:10.1787/9789264073173-en.

[4] Fuel Cell Today, Fuel Cell Electric Vehicles: The Road Ahead, 2012.

[5] Alexander Körner, Technology Roadmap: Hydrogen and Fuel Cells (Technical Annex), International Energy Agency (IEA), 2015. doi:10.1007/SpringerReference_7300.

[6] J2601: Fueling Protocols for Light Duty Gaseous Hydrogen Surface Vehicles - SAE International, (2016) 140.

[7] K. Wipke, S. Sprik, J. Kurtz, T. Ramsden, C. Ainscough, G. Saur, National Fuel Cell Electric Vehicle Learning Demonstration Final Report, 2012.

[8] G. Parks, R. Boyd, J. Cornish, R. Remick, Hydrogen Station Compression, Storage, and Dispensing Technical Status and Costs: Systems Integration, 2014. doi:10.2172/1130621.

[9] N. Arjomand Kermani, M. Rokni, Heat transfer analysis of liquid piston compressor for hydrogen applications, Int. J. Hydrogen Energy. 40 (2015) 11522-11529.

doi:10.1016/j.ijhydene.2015.01.098.

[10] Report, Linde Technology, (2006). http://www.the-lindegroup.com/internet.global.thelindegroup.global/en/images/Linde_Technology_1_2006_EN14_1 0188.pdf.

[11] R. Klippstein, P. Contact, T. Carlson, D. Chalk, N. Pugliese, M. Rice, et al., Novel Compression and Fueling Apparatus to Meet Hydrogen Vehicle Range Requirements Contribution to Achievement of U.S. Department of Energy (DOE) Technology Validation Milestones, 2006.

[12] E. Schluecker, L. Szarvas, E. Uerdingen, New developments in pumps and compressors using ionic liquids, ACHEMA World Wide News. (2008) 5-7.

http://wbt.dechema.de/achema2009_media/Downloads/Presse/05_07_New_developments.pdf (accessed July 27, 2014).

[13] T. Predel, E. Schlücker, Ionic liquids in oxygen compression, Chem. Eng. Technol. 32 (2009) 1183-1188. doi:10.1002/ceat.200900047.

[14] E.S. C. Muller, M. Sesing, M. Fiene, O. Huttenloch, Method for operating a liquid ring compressor, Pub. No.: US 2007/02669309, 2011. http://www.google.com/patents/US7927080 (accessed July 27, 2014).

[15] E.S. C. Hilgers, M. Uerdingen, M. Wanger, P. wasserscheid, Processing and/or operating machine comprising an ionic liquid as the operating liquid, Pub. No.: US 2008/0038123 A1, 2008. http://www.google.com/patents/US20080038123 (accessed July 27, 2014).

[16] Y. Wang, T. Lee, J. Lin, J. Chang, C. Tseng, Corrosion properties of metals in dicyanamide- 
based ionic liquids, Corros. Sci. 78 (2014) 81-88. doi:10.1016/j.corsci.2013.09.002.

[17] R. Reddy, Z. Zhang, Thermal stability and corrosivity evaluations of ionic liquids as thermal energy storage media, High Temp. Mater. Process. 22 (2003) 87-94. $\mathrm{http}: / / \mathrm{www}$. degruyter.com/dg/viewarticle.fullcontentlink:pdfeventlink/\$002fj\$002fhtmp.2003.22 $.2 \$ 002 \mathrm{fhtmp} .2003 .22 .2 .87 \$ 002 \mathrm{fhtmp} .2003 .22 .2 .87 . \mathrm{pdf} ? \mathrm{t}: \mathrm{ac}=\mathrm{j} \$ 002 \mathrm{fhtmp} .2003 .22 .2 \$ 002 \mathrm{fhtmp} .2$ 003.22.2.87\$002fhtmp.2003.22.2.87.xml (accessed October 17, 2014).

[18] P.-C. Lin, I.-W. Sun, J.-K. Chang, C.-J. Su, J.-C. Lin, Corrosion characteristics of nickel, copper, and stainless steel in a Lewis neutral chloroaluminate ionic liquid, Corros. Sci. 53 (2011) 43184323. doi:10.1016/j.corsci.2011.08.047.

[19] C.-H. Tseng, J.-K. Chang, J.-R. Chen, W.T. Tsai, M.-J. Deng, I.-W. Sun, Corrosion behaviors of materials in aluminum chloride-1-ethyl-3-methylimidazolium chloride ionic liquid, Electrochem. Commun. 12 (2010) 1091-1094. doi:10.1016/j.elecom.2010.05.036.

[20] I. Perissi, U. Bardi, S. Caporali, A. Lavacchi, High temperature corrosion properties of ionic liquids, Corros. Sci. 48 (2006) 2349-2362. doi:10.1016/j.corsci.2006.06.010.

[21] M. Uerdingen, C. Treber, M. Balser, G. Schmitt, C. Werner, Corrosion behaviour of ionic liquids, Green Chem. 7 (2005) 321. doi:10.1039/b419320m.

[22] I.S. Molchan, G.E. Thompson, R. Lindsay, P. Skeldon, V. Likodimos, G.E. Romanos, et al., Corrosion behaviour of mild steel in 1-alkyl-3-methylimidazolium tricyanomethanide ionic liquids for CO2 capture applications, RSC Adv. 4 (2014) 5300. doi:10.1039/c3ra45872e.

[23] a. B. Tolstoguzov, U. Bardi, S.P. Chenakin, Study of the corrosion of metal alloys interacting with an ionic liquid, Bull. Russ. Acad. Sci. Phys. 72 (2008) 605-608. doi:10.3103/S1062873808050080.

[24] Iolitec - Ionic Liquids Technologies, (n.d.). http://www.iolitec.de/en/Company/company.html (accessed August 29, 2014).

[25] M.G. Freire, A.R.R. Teles, M.A.A. Rocha, B. Schröder, C.M.S.S. Neves, P.J. Carvalho, et al., Thermophysical Characterization of Ionic Liquids Able To Dissolve Biomass, J. Chem. Eng. Data. 56 (2011) 4813-4822. doi:10.1021/je200790q.

[26] C. Schreiner, S. Zugmann, R. Hartl, H.J. Gores, Fractional Walden Rule for Ionic Liquids: Examples from Recent Measurements and a Critique of the So-Called Ideal $\mathrm{KCl}$ Line for the Walden Plot $\uparrow$, J. Chem. Eng. Data. 55 (2010) 1784-1788. doi:10.1021/je900878j.

[27] S. Zhang, N. Sun, X. He, X. Lu, X. Zhang, Physical Properties of Ionic Liquids: Database and Evaluation, J. Phys. Chem. Ref. Data. 35 (2006) 1475. doi:10.1063/1.2204959.

[28] A. Bhattacharjee, A. Luís, J.A. Lopes-da-Silva, M.G. Freire, P.J. Carvalho, J.A.P. Coutinho, Thermophysical properties of sulfonium- and ammonium-based ionic liquids., Fluid Phase Equilib. 381 (2014) 36-45. doi:10.1016/j.fluid.2014.08.005.

[29] A.P. Fröba, H. Kremer, A. Leipertz, Density, refractive index, interfacial tension, and viscosity of ionic liquids [EMIM][EtSO4], [EMIM][NTf2], [EMIM][N(CN)2], and [OMA][NTf2] in dependence on temperature at atmospheric pressure., J. Phys. Chem. B. 112 (2008) 12420-30. doi:10.1021/jp804319a. 
[30] Sigma Aerospace Metals - Sigma Aerospace Metals, LLC, (n.d.). http://www.sigmaaero.com/ (accessed August 29, 2014).

[31] Keramische Oberflächenbeschichtung, Coatings und temperaturbeständige Beschichtungen, (n.d.). http://www.ceprotec.de/ (accessed September 1, 2014).

[32] DANSK AEDELMETAL, (n.d.). http://www.dansk.aedelmetal.dk/index.php (accessed September 1, 2014).

[33] Heraeus - Precious metals and technology Group, (n.d.). http://www.heraeus.com/en/home.html (accessed September 1, 2014).

[34] N. Bjerrum, I. Petrushina, R. Berg, Electrochemical investigation of the catalytical processes in sulfuric acid production, J. Electrochem. Soc. 142 (1995) 1805-1813. http://jes.ecsdl.org/content/142/6/1805.short (accessed July 28, 2014).

[35] I. Petrushina, N. Bjerrum, Electrochemical behavior of molten V2O5-K2S207-KHSO4 systems, ... Electrochem. Soc. 144 (1997) 532-539. http://jes.ecsdl.org/content/144/2/532.short (accessed July 28, 2014).

[36] L. Meites, Handbook of Analytical Chemistry, McGraw Hill, 1963. http://www.amazon.com/Handbook-Analytical-Chemistry-Louis-Meites/dp/0070413363 (accessed July 28, 2014).

[37] Struers Ensuring Certainty, (n.d.). http://www.struers.com/ (accessed October 13, 2016).

[38] OMEGA Engineering Company, (n.d.). http://www.omega.com/ (accessed February 17, 2016).

[39] VersaStudio, (n.d.). http://www.princetonappliedresearch.com/Our-Products/ElectrochemicalSoftware/VersaStudio.aspx (accessed September 1, 2014).

[40] P.A. Tempest, R.K. Wild, Oxidation pretreatment to reduce corrosion of $20 \% \mathrm{Cr}-25 \% \mathrm{Ni}-\mathrm{Nb}$ stainless steel. I. Weight gain and oxide thickness measurements, Oxid. Met. 30 (1988) 209-230. doi:10.1007/BF00666598.

[41] D. Deb, S.R. Iyer, V.M. Radhakrishnan, A comparative study of oxidation and hot corrosion of a cast nickel base superalloy in different corrosive environments, Mater. Lett. 29 (1996) 19-23. doi:10.1016/S0167-577X(96)00109-7.

[42] K.R. Tretheway, Corrosion for students of science and engineering, Longman, 1988.

[43] ASTM International - Annual Book of ASTM Standards 10.05, g3-89, n.d. http://www.astm.org/BOOKSTORE/BOS/ (accessed July 28, 2014).

[44] A.V. Nikiforov, I.M. Petrushina, E. Christensen, A.L. Tomás-García, N.J. Bjerrum, Corrosion behaviour of construction materials for high temperature steam electrolysers, Int. J. Hydrogen Energy. 36 (2011) 111-119. doi:10.1016/j.ijhydene.2010.09.023.

[45] M.G. Fontana, Corrosion Engineering, McGraw Hill, New York, 1967.

[46] N.A. Kermani, I. Petrushina, A. Nikiforov, J.O. Jensen, M. Rokni, Corrosion behavior of construction materials for ionic liquid hydrogen compressor, Int. J. Hydrogen Energy. 41 (2016) 16688-16695. doi:10.1016/j.ijhydene.2016.06.221.

[47] A.B. McEwen, Electrochemical Properties of Imidazolium Salt Electrolytes for Electrochemical 
Capacitor Applications, J. Electrochem. Soc. 146 (1999) 1687. doi:10.1149/1.1391827.

[48] H. Weingärtner, P. Sasisanker, C. Daguenet, P.J. Dyson, I. Krossing, J.M. Slattery, et al., The dielectric response of room-temperature ionic liquids: effect of cation variation., J. Phys. Chem. B. 111 (2007) 4775-80. doi:10.1021/jp0671188.

[49] S.B. Lyon, Corrosion of tantalum and niobium and their alloys, Shreir's Corros. (2010) 21352150. doi:10.1016/B978-044452787-5.00102-5.

[50] G.D. Smith, The effect of niobium on the corrosion resistance of nickel-base alloys, Proc. Int. Symp. Niobium High Temp. Appl. (2004) 23-34.

[51] J.A. Widegren, E.M. Saurer, K.N. Marsh, J.W. Magee, Electrolytic conductivity of four imidazolium-based room-temperature ionic liquids and the effect of a water impurity, J. Chem. Thermodyn. 37 (2005) 569-575. doi:10.1016/j.jct.2005.04.009.

[52] U. Schröder, J.D. Wadhawan, R.G. Compton, F. Marken, P.A.Z. Suarez, C.S. Consorti, et al., Water-induced accelerated ion diffusion: voltammetric studies in 1-methyl-3-[2,6-(S)dimethylocten-2-yl]imidazolium tetrafluoroborate, 1-butyl-3-methylimidazolium tetrafluoroborate and hexafluorophosphate ionic liquids, New J. Chem. 24 (2000) 1009-1015. doi: $10.1039 / \mathrm{b} 007172 \mathrm{~m}$.

[53] R. Aranowski, I. Cichowska-Kopczyńska, B. Dębski, P. Jasiński, Conductivity and viscosity changes of imidazolium ionic liquids induced by H2o and Co2, J. Mol. Liq. 221 (2016) 541546. doi:10.1016/j.molliq.2016.06.010.

[54] J.-M. Andanson, X. Meng, M. Traïkia, P. Husson, Quantification of the impact of water as an impurity on standard physico-chemical properties of ionic liquids, J. Chem. Thermodyn. 94 (2016) 169-176. doi:10.1016/j.jct.2015.11.008.

[55] A.M. O'Mahony, D.S. Silvester, L. Aldous, C. Hardacre, R.G. Compton, Effect of Water on the Electrochemical Window and Potential Limits of Room-Temperature Ionic Liquids, J. Chem. Eng. Data. 53 (2008) 2884-2891. doi:10.1021/je800678e.

[56] J.A. Widegren, A. Laesecke, J.W. Magee, The effect of dissolved water on the viscosities of hydrophobic room-temperature ionic liquids., Chem. Commun. (Camb). (2005) 1610-2. doi:10.1039/b417348a.

[57] M.S. Kelkar, E.J. Maginn, Effect of temperature and water content on the shear viscosity of the ionic liquid 1-ethyl-3-methylimidazolium bis(trifluoromethanesulfonyl)imide as studied by atomistic simulations., J. Phys. Chem. B. 111 (2007) 4867-76. doi:10.1021/jp0686893.

[58] R.P. Morco, A.Y. Musa, M. Momeni, J.C. Wren, Corrosion of carbon steel in the [P14666][Br] ionic liquid: The effects of $\gamma$-radiation and cover gas, Corros. Sci. 102 (2016) 1-15. doi:10.1016/j.corsci.2015.06.027. 


\section{Highlights}

- Corrosion behavior of stainless steels and nickel-based alloys was evaluated at $80^{\circ} \mathrm{C}$

- Suitable construction material for ionic liquid hydrogen compressor has been found

- AISI 347 showed very high corrosion resistance in all of the tested ionic liquids

- The ILs viscosity and water content play key role in alloys corrosion behavior

- The highest corrosion resistance of the alloys is observed in [P66614][Tf2N] IL 